\title{
PENGARUH PENERAPAN METODE TEAMS GAMES TOURNAMENT BERBANTUAN PERMAINAN DADU TERHADAP HASIL BELAJAR IPA
}

\author{
Eka Rizki Widayanti \\ Slameto \\ Program Studi PGSD-FKIP, Universitas Kristen Satya Wacana \\ Jl. Diponegoro 52-60, Salatiga 50711, Indonesia \\ 292012219@student.uksw.edu \\ slameto_uksw@yahoo.com
}

\begin{abstract}
ABSTRAK
Berdasarkan observasi ketika mengikuti pembelajaran siswa kelas 3 terlihat tidak tertarik dalam mengikuti pembelajaran sehingga siswa cenderung pasif dan pembelajaran tampak membosankan. Tujuan penelitian ini adalah untuk membuktikan perbedaan yang signifikan antara penerapan metode pembelajaran Teams Games Tournament berbantuan permainan dadu dengan metode pembelajaran diskusi terhadap pencapaian hasil belajar IPA pada siswa kelas 3 SDN Lemahireng 02 Bawen Semester II Tahun Ajaran 2015/2016 sehingga siswa menjadi tertarik dan merasa senang mengikuti pembelajaran. Jenis penelitian ini adalah Pre-Eksperimental Design, dengan desain OneGroup Pretest-Postest Design. Teknik analisis data menggunakan uji t (Paired samples $t$ test ) dengan taraf signifikansi $=0,05$. Hasil penelitian menunjukkan bahwa terdapat perbedaan yang signifikan antara penerapan metode pembelajaran Teams Games Tournament berbantuan permainan dadu dengan metode pembelajaran diskusi terhadap pencapaian hasil belajar IPA pada siswa kelas 3 SDN Lemahireng 02 Bawen. Hal ini dikarenakan siswa tertarik dan merasa senang dalam mengikuti pembelajaran dan dibuktikan dengan hasil rata-rata nilai posttest setelah diberikan perlakuan menggunakan metode Teams Games Tournament berbantuan permainan dadu yaitu sebesar 72,1 dibandingkan dengan rata-rata pretest sebelum diberikan perlakuan yaitu sebesar 57. Berdasarkan hasil penelitian disarankan menggunakan metode pembelajaran Teams Games Tournament berbantuan permainan dadu yang dapat digunakan sebagai salah satu cara untuk meningkatkan hasil belajar siswa dalam pelajaran IPA.
\end{abstract}

Kata Kunci: Metode Teams Games Tournament, permainan dadu, hasil belajar, IPA.

\section{PENDAHULUAN}

Keberhasilan belajar akan tercapai apabila antara pendidik, peserta didik, dan lingkungan saling mendukung. Menurut Supriadi (dalam Hamdani, 2011: 4) tugas pendidik dalam rangka optimalisasi proses belajar mengajar salah satunya ialah mengembangkan kondisi belajar yang relevan agar tercipta suasana belajar yang menyenangkan. Ketepatan dalam penggunaan metode pembelajaran bergantung pada kesesuaian metode pembelajaran dengan beberapa faktor salah satu diantaranya ialah mata pelajaran dan kondisi peserta didik.

Ilmu Pengetahuan Alam (IPA) ialah mata pelajaran yang berhubungan dengan cara mencari tahu mengenai alam secara sistematis, sehingga tidak hanya penguasaan kumpulan pengetahuan yang berupa fakta, konsep, atau prinsip saja tetapi juga merupakan proses penemuan (Depdiknas, 2006). 
Berdasarkan hasil observasi yang dilakukan di SDN Lemahireng 02 Kabupaten Semarang, hasil belajar IPA kelas 3 dari 27 siswa ada 18 siswa yang belum mencapai Kriteria Ketuntasan Minimal (KKM) yaitu 63. Hal tersebut menunjukkan bahwa dalam pelaksanaan kegiatan belajar mengajar belum mencapai tujuan yang diharapkan. Melihat kenyataan yang terjadi di sekolah tersebut, pelaksanaan pembelajaran IPA belum dikatakan berhasil. Berdasarkan hasil wawancara mengenai pembelajaran IPA dengan siswa kelas 3 SDN Lemahireng 02, ada 10 siswa dari 13 siswa yang diwawancara berpendapat bahwa pembelajaran IPA materinya sulit untuk dipahami dan materinya banyak. Hasil wawancara yang dilakukan dengan guru dan siswa kelas 3 SDN Lemahireng 02 Bawen, dapat dikatakan bahwa pembelajaran masih terlihat berpusat pada guru. Metode pembelajaran yang digunakan kurang sesuai dengan karakteristik atau kondisi siswa, lingkungan, dan materi yang dipelajari. Hal tersebut menyebabkan siswa kurang tertarik dalam mengikuti pembelajaran. Jika hal tersebut dibiarkan, tentu saja ini akan berdampak pada ketertarikan siswa dalam mengikuti kegiatan belajar mengajar, yang tentunya akan berakibat hasil belajar IPA siswa rendah.

Menurut Jean Piaget dalam (Penny, 2012: 178-179) tahap perkembangan kognitif dan moral pada anak sekolah dasar, anak-anak belajar melalui permainan di lapangan bermain dengan berinteraksi bersama rekan sebayanya. Supaya perkembangan kognitif anak-anak berjalan baik, dibutuhkan salah satu bentuk pembelajaran yaitu model pembelajaran kooperatif. Menurut Wina Sanjaya dalam (Hamdani, 2012: 30) model pembelajaran kooperatif merupakan rangkaian kegiatan belajar peserta didik didalam kelompok tertentu guna mencapai tujuan pembelajaran yang dirumuskan. Karena pada anak usia sekolah dasar kelas 3 termasuk usia anak yang masih senang bermain, maka peneliti memilih pembelajaran kooperatif tipe Teams Games Tournament.

Pembelajaran kooperatif tipe Teams Game Tournament ialah salah satu metode pembelajaran kooperatif yang melibatkan aktivitas peserta didik, melibatkan peran peserta didik sebagai tutor sebaya, dan mengandung unsur permainan. Karena pembelajaran dilakukan dengan bermain, dimungkinkan timbul rasa senang dari peserta didik untuk mengikuti pembelajaran. Dengan adanya ketertarikan yang ditimbulkan dalam mengikuti pembelajaran, maka dimungkinkan hasil belajar juga lebih baik.

Berdasarkan pendapat yang dikemukakan oleh Schunk (2012: 464) bahwa rekan sebaya berdampak pada motivasi peserta didik, selanjutnya teori dari Hamalik (2010: 108) dimana ketertarikan dalam mengikuti pembelajaran menentukan tingkat berhasil atau gagalnya kegiatan belajar peserta didik yang dapat dilihat melalui hasil belajar serta teori dari Piaget bahwa anak-anak belajar dengan bersama rekan sebaya, timbul ketertarikan untuk melakukan penelitian tentang pengaruh penerapan metode pembelajaran Teams Game Tournament berbantuan permainan dadu terhadap hasil belajar.

Berdasarkan paparan penjelasan latar belakang maka penulis merumuskan masalah yaitu apakah terdapat perbedaan penerapan metode pembelajaran Teams Game Tournament berbantuan permainan dadu dengan metode pembelajaran diskusi terhadap pencapaian hasil belajar IPA pada siswa kelas 3 SDN Lemahireng 02 Bawen Semester II Tahun Ajaran 2015/2016. Tujuan yang hendak dicapai dari penelitian ini adalah untuk membuktikan perbedaan yang signifikan antara penerapan metode pembelajaran Teams 
Game Tournament berbantuan permainan dadu dengan metode pembelajaran diskusi terhadap pencapaian hasil belajar IPA pada siswa kelas 3 SDN Lemahireng 02 Bawen Semester II Tahun Ajaran 2015/2016 sehingga siswa menjadi tertarik dan merasa senang mengikuti pelajaran.

Dari tujuan yang telah dirumuskan, maka hasil penelitian ini diharapkan mampu memberikan sumbangan pada dunia pendidikan dan dapat bermanfaat pada masyarakat luas, khususnya pada bidang pendidikan. Manfaat penelitian ini ialah manfaat teoritis dimana penggunaan metode pembelajaran Teams Game Tournament berbantuan permainan dadu dapat digunakan sebagai salah satu cara yang dapat meningkatkan hasil belajar peserta didik dalam pelajaran IPA.

\section{KAJIAN PUSTAKA}

\section{Ilmu Pengetahuan Alam (IPA)}

IPA ialah ilmu yang berhubungan dengan gejala alam yang disusun secara sistematis berdasarkan hasil pengamatan dan percobaan yang dikumpulkan dan disusun secara teratur dimana pengetahuan itu saling berkaitan sehingga antara satu dengan yang lainnya merupakan satu kesatuan yang utuh (Powler dalam Usman Samatowa, 2011: 3). Selanjutnya menurut Folwer (Trianto, 2014:136) "IPA ialah pengetahuan yang sistematis yang dirumuskan, yang berhubungan dengan gejala-gejala kebendaan dan didasarkan terutama atas pengamatan dan dedukasi”.

Menurut Usman Samatowa (2011: 4) IPA mampu melatih anak untuk berpikir kritis dan objektif, sehingga IPA bermanfaat bagi suatu bangsa karena IPA merupakan dasar teknologi. Hal ini sejalan dengan yang tertuang dalam KTSP Standar Isi 2006, Pembelajaran IPA diharapkan dapat menjadi wahana bagi peserta didik untuk mempelajari diri sendiri dan alam sekitar, serta prospek pengembangan lebih lanjut dalam menerapkannya dalam kehidupan sehari-hari. Sehingga pembelajaran IPA mempunyai pengaruh penting dalam kehidupan manusia pada umumnya karena dengan adanya pembelajaran IPA, manusia akan termotivasi untuk melakukan penemuan dan inovasi untuk menunjang kehidupannya. Pembelajaran IPA di Sekolah Dasar mampu melatih dan memberikan kesempatan siswa untuk mengembangkan keterampilan-keterampilan proses dan mampu melatih siswa untuk dapat berpikir serta bertindak secara rasional dan kritis terhadap persoalan yang bersifat ilmiah yang terjadi di lingkungan sekitarnya. Keterampilan-keterampilan yang diberikan kepada siswa sebisa mungkin disesuaikan dengan tingkat perkembangan usia dan karakteristik siswa Sekolah Dasar, sehingga siswa juga mampu menerapkannya dalam kehidupannya sehari-hari.

Pembelajaran IPA di SD, hendaknya tidak hanya fokus pada upaya pencapaian akademik semata, tetapi juga mengembangkan keterampilan proses untuk menyelidiki alam sekitar, memecahkan masalah, dan membuat keputusan. Dengan demikian, semakin jelas bahwa proses belajar mengajar IPA lebih ditekankan pada pendekatan keterampilan proses, sehingga siswa mampu menemukan sendiri fakta, konsep teori, dan sikap ilmiah yang diharapkan mampu memiliki sikap ilmiah kritis, kreatif dan mandiri yang nantinya dapat berpengaruh baik dalam proses pendidikan maupun produk pendidikan. 
Pembelajaran IPA, sebaiknya melibatkan siswa secara aktif dalam kegiatan yang memungkinkan siswa untuk membangun pengetahuanya sendiri.

\section{Teams Games Tournament (TGT)}

Teams Games Tournament merupakan salah satu model pembelajaran kooperatif yang biasa disebut dengan Pertandingan Permainan Tim yang dikembangkan oleh David De Vries dan Keath Edward. Fathurrohman (2015: 55) menjelaskan bahwa pembelajaran kooperatif Teams Game Tournament ialah salah satu dari model pembelajaran kooperatif yang menempatkan siswa dalam kelompok belajar beranggotakan 3-6 orang dimana anggota kelompok dipilih secara heterogen.

Langkah-langkah (sintaks) dalam metode pembelajaran Teams Games Tournament ada 4 yaitu penyajian materi, belajar bersama kelompok, melakukan turnamen, dan penghargaan kelompok. Kelompok terdiri dari 3 hingga 6 orang. Dalam pemilihan anggota kelompok, anggota yang dipilih harus heterogen sesuai dengan jenis kelamin, suku, dan prestasi akademik yang dimiliki siswa. Pemilihan anggota kelompok yang heterogen diharapkan mampu membuat siswa menjadi lebih bertanggung jawab dan mampu bekerjasama dalam kelompok. Turnamen yang dilakukan dibuat dengan permainan yang menggunakan kuis berisi pertanyaan yang berhubungan dengan materi untuk mengetahui tingkat pemahaman siswa. Berdasarkan Permendiknas No. 41 Tahun 2007 tentang standar proses, pelaksanaan pembelajaran ialah implementasi dari Rencana Pelaksanaan Pembelajaran (RPP). Pelaksanaan pembelajaran terdiri dari tiga tahapan yang harus dilakukan, yaitu: tahap kegiatan pendahuluan, tahap kegiatan inti, dan tahap kegiatan penutup.

Metode Teams Games Tournament dapat diterapkan dalam mata pelajaran IPA dimana peserta didik bekerja dalam kelompok, belajar sambil bermain sehingga peserta didik merasa senang mengikuti kegiatan pembelajaran. Sedangkan IPA didefinisikan sebagai kumpulan dari pengetahuan yang disusun hasil dari percobaan dan pengamatan secara teratur sehingga saling berkaitan sebagai suatu kesatuan yang utuh. Selain itu, IPA tidak hanya sekedar mencari tahu tetapi juga membutuhkan berpikir, melakukan suatu kegiatan, dan memecahkan masalah yang terjadi. IPA juga merupakan kumpulan dari pengetahuan yang disusun hasil dari percobaan dan pengamatan secara teratur sehingga saling berkaitan sebagai suatu kesatuan yang utuh. Selain itu, IPA tidak hanya sekedar mencari tahu tetapi juga membutuhkan berpikir, melakukan suatu kegiatan, dan memecahkan masalah yang terjadi. Dengan demikian, pengetahuan yang diperoleh dan cara pemecahan masalah yang terjadi dapat melalui kerjasama dengan orang lain sehingga antara satu pendapat dengan pendapat lain dapat saling melengkapi. Sehingga pembelajaran menggunakan metode Teams Games Tournament tepat untuk diterapkan pada pelajaran IPA yang membutuhkan kerjasama dan akan menimbulkan ketertarikan dalam belajar yang disebabkan rasa senang dalam melakukan kegiatan pembelajaran yang akan berdampak pada hasil belajar.

\section{Permainan Dadu}

Dalam perkembangan anak usia Sekolah Dasar, proses pembelajarannya masih suka dengan kegiatan bermain, maka dari itu strategi pembelajaran yang dapat dilakukan 
pendidik yaitu dengan belajar sambil bermain. Permainan adalah cara bermain dengan mengikuti aturan tertentu yang dapat dilakukan secara individu maupun berkelompok untuk mencapai tujuan tertentu. Pembelajaran di sekolah dimana guru yang menjadi pelaku dalam kegiatan belajar mengajar, guru mempunyai peran dalam menanggapi kegiatan atas inisiatif sendiri dengan tetap membiarkan anak-anak bergerak bebas secara aktif membentuk pengetahuannya dengan bermain (Neville Bannett, 2005: 17).

Menurut Bruner (Neville Bannett, 2005: 18), permainan bertindak sebagai wahana sosialisasi, termasuk mengajari anak-anak mengenai konvensional sosial dan sifat kaidah dimana anak-anak mempelajari kaidah, peran, hubungan, bentuk perilaku, keterampilan berteman, serta akibat dari tindakan mereka terhadap orang lain.

Permainan dadu adalah permainan yang menggunakan bujur sangkar. Bujur sangkar mempunyai enam sisi dengan panjang rusuk yang sama panjang. Cara permainan dadu adalah dengan memberi satu angka dimana angka itu merupakan suatu kunci untuk membuka soal yang tertera pada sisi dadu.

Dalam melakukan permainan, pemain merasa lebih senang apalagi jika permainan dilakukan oleh anak usia SD. Permainan dapat dipadukan dengan belajar mengingat belajar merupakan hal yang sangat penting dalam menjalani kehidupan. Dalam melakukan kegiatan belajar yang dipadukan dengan bermain, seseorang dapat terpancing untuk mengikuti pembelajaran karena dalam permainan menjadikan peserta didik merasa tertarik sehingga merasa senang dan menjadikan lebih aktif. Jika dalam belajar yang dipadukan dengan bermain dilakukan secara berkelompok, peserta didik menjadi dapat bekerja sama dengan rekan sebayanya untuk memecahkan suatu masalah sehingga peserta didik dapat lebih percaya diri untuk berteman dengan siapa saja tanpa membedakan teman dan lebih bertanggung jawab.

Dalam melaksanakan pembelajaran yang dipadukan dengan bermain, kesuksesan kegiatan harus didukung oleh beberapa pihak diantaranya peran guru, sekolah, jadwal, situasi dan kondisi ruang kelas. Permainan mempunyai kelebihan diantaranya akan membuat peserta didik menjadi lebih antusias dan merasa tidak tertekan sehingga jika pembelajaran dipadukan dengan bermain maka peserta didik menjadi lebih tertarik untuk mengikuti pembelajaran. Selain itu, dalam pelaksanaan pembelajaran yang dipadukan dengan permainan hendaknya memperhatikan beberapa faktor diantaranya materi, karakteristik peserta didik, dan waktu agar pembelajaran dapat dilakukan secara efektif. Jika dalam melaksanakan pembelajaran yang dipadukan dengan bermain sudah memperhatikan faktor-faktor dan peserta didik juga sudah tertarik dan merasa senang dalam mengikuti kegiatan pembelajaran maka diharapkan materi yang disampaikan dalam tujuan pembelajaran dapat tercapai hal ini berarti hasil belajar yang diharapkan juga tercapai.

\section{Hasil Belajar}

Pendidikan selalu berkaitan dengan belajar, belajar dapat dikatakan berhasil atau tidak berhasil dalam mencapai tujuan dengan mengukur hasil belajar. Menurut Rusman (2012:123) hasil belajar adalah sejumlah pengalaman yang diperloreh siswa yang mencakup ranah kognitif, afektif, dan psikomotorik. Dalam melakukan kegiatan hasil 
belajar, dilakukan dengan pemberian nilai sehingga dapat menunjukkan kualitas yang dinilai.

Rusman (2012: 123-124) mengungkapkan bahwa hasil belajar mempunyai peranan penting dalam proses pembelajaran, yaitu proses penilaian terhadap hasil belajar. Proses penilaian terhadap hasil belajar dapat memberikan data atau informasi kepada guru tentang kemajuan peserta didik dalam upaya mencapai tujuan belajarnya melalui kegiatan belajar. Hasil belajar sangat penting dilakukan dalam dunia pendidikan. Hasil belajar peserta didik mempunyai peranan penting bagi peserta didik untuk mengetahui sejauh mana tingkat keberhasilan dalam mengikuti pelajaran yang disajikan guru, bagi guru untuk mengetahui peserta didik dalam mencapai KKM yang telah ditentukan sebelumnya serta penentuan penggunaan strategi pembelajaran yang sudah sesuai atau belum, dan bagi sekolah guna mengetahui apakah kondisi belajar maupun kultur akademik sesuai dengan harapan serta sebagai pedoman untuk mengetahui apakah yang dilakukan oleh sekolah sudah memenuhi standar pendidikan sebagaimana dituntut Standar Nasional Pendidikan (SNP), sehingga sekolah dapat menyusun berbagai program pendidikan untuk masa-masa mendatang di sekolah. Hasil belajar dapat dilihat melalui kegiatan evaluasi yang bertujuan untuk mendapatkan informasi data pembuktian yang akan menunjukkan tingkat kemampuan siswa dalam mencapai tujuan pembelajaran, sehingga akan diketahui sejauh mana keberhasilan peserta didik dalam mengikuti pelajaran yang disajikan guru. Apabila tujuan pembelajaran telah tercapai maka guru berhak melanjutkan materi selanjutnya dalam pembelajaran.

Untuk mengetahui hasil belajar dapat dilakukan dengan menggunakan Teknik atau alat evaluasi. Menurut Wina Sanjaya (2008: 354) dalam melakukan penilaian hasil belajar dapat dikelompokkan menjadi dua yaitu tes dan non tes. Menurut Rusman (2012: 1260) hasil belajar yang diharapkan bergantung pada jenis dan karakteristik materi dan mata pelajaran yang disampaikan, ada mata pelajaran yang terfokus pada dominan dengan tujuan kognitif, afektif, ataupun psikomotorik.

Hasil belajar merupakan proses yang cukup kompleks, artinya bahwa hasil belajar siswa dipengaruhi oleh beberapa faktor yang mendukung, yaitu: 1) faktor internal meliputi: faktor fisiologis dan faktor psikologis; 2) faktor eksternal meliputi: faktor lingkungan sosial dan non lingkungan sosial, serta peran siswa, peran guru, serta model yang digunakan dalam pembelajaran. Maka untuk memaksimalkan situasi, kondisi, dan kemampuan yang telah dimiliki oleh siswa, penelitian ini mencoba menggunakan metode Teams Game Tournament dalam pembelajaran IPA. Teams Game Tournament merupakan metode pembelajaran yang berperan untuk melibatkan peserta didik untuk terlibat aktif dalam Proses Belajar Mengajar (PBM) berlangsung bersama rekan sebayanya dengan unsur permainan, siswa diarahkan untuk berusaha bertanggung jawab atas dirinya sendiri dan kelompok. Sehingga dengan belajar sambil bermain dengan rekan sebaya akan menumbuhkan ketertarikan dalam mengikuti pembelajaran dan karena timbulnya ketertarikan dan rasa yang menyenangkan maka pengetahuan yang didapatkan dalam belajar sambil bermain akan tersimpan lebih lama dalam ingatan siswa, sehingga siswa akan lebih aktif dan mudah dalam menguasai materi yeng telah diberikan oleh guru, yang tentunya akan berpengaruh pada hasil belajar siswa. 


\section{Kajian Penelitian yang Relevan}

Penelitian yang dilakukan oleh Sari dan Ika Ayu Kartika (2012) menunjukan adanya peningkatan antusias dan tertariknya siswa dalam belajar yang berdampak pada meningkatnya hasil belajar. Pada akhir siklus telah diperoleh hasil bahwa 35 siswa dari 36 siswa memiliki antusias belajar fisika dengan kategori baik. Peningkatan antusias dan tertariknya siswa dalam belajar ini berdampak pada peningkatan prestasi belajar siswa dari kondisi awal sebelum diberi perlakuan sampai pada siklus I ke siklus II. Berdasarkan hasil penelitian dapat diambil kesimpulan bahwa prestasi hasil belajar siswa mengalami peningkatan melalui penerapan model Teams Game Tournament dengan metode permainan monopoli.

Selanjutnya penelitian yang dilakukan oleh Sri Yamtinah dan Suryadi Budi Utomo (2012) menunjukkan bahwa terdapat pengaruh signifikan dalam penerapan metode Teams Game Tournament berbantuan media TTS dan ular tangga pada pembelajaran materi koloid terhadap prestasi belajar kimia dibuktikan dengan nilai signifikansi ( $0<0,05)$ dan selisih nilai kognitif pada kelas eksperimen 1 lebih baik daripada kelas eksperimen 2, karena pembelajaran dengan metode Teams Game Tournament berbantuan media TTS siswa lebih fokus dan teliti dalam menjawab pertanyaannnya yang disesuaikan dengan jumlah kotak kosong yang telah disediakan. Selain itu juga tidak ada interaksi antara penerapan metode Teams Game Tournament berbantuan media TTS dan ular tangga dengan motivasi belajar siswa pada pembelajaran materi koloid terhadap prestasi belajar kimia, karena siswa yang memiliki motivasi belajar tinggi prestasi belajarnya tidak secara signifikan dipengaruhi oleh media baik permainan TTS maupun ular tangga.

Penelitian lain yang dilakukan oleh Agustini, Dibia, dan Suartama (2014) menunjukkan perbedaan hasil belajar IPA yang signifikan antara siswa belajar dengan metode pembelajaran kooperatif tipe Teams Games Tournament berbantuan media flip chart dan siswa yang belajar menggunakan model pembelajaran konvensional dengan $\mathrm{t}$ hitung $>\mathrm{t}$ tabel $\left(\mathrm{t}_{\text {hitung }}=4,181>\mathrm{t}\right.$ tabel $\left.=2,021\right)$. Dengan demikian membuktikan bahwa metode pembelajaran Teams Game Tournament berbantuan media flip chart berpengaruh signifikan terhadap hasil belajar siswa dalam pembelajaran IPA dibandingkan dengan model pembelajaran konvensional.

\section{METODE PENELITIAN}

Penelitian yang digunakan ialah jenis penelitian eksperimen. Penelitian eksperimen (experimental research) adalah metode penelitian yang dilaksanakan untuk mencari pengaruh perlakuan tertentu terhadap objek penelitian dalam kondisi yang terkendalikan (Sugiyono, 2014:72). Penelitian eksperimen merupakan penelitian dengan tujuan untuk mengetahui atau menilai suatu pengaruh dari suatu perlakuan/ tindakan/ treatment pendidikan terhadap perilaku siswa atau menguji hipotesis tentang ada tidaknya pengaruh tindakan itu bila dibandingkan dengan tindakan lain.

Desain penelitian eksperimen yang digunakan dalam penelitian ini ialah one group pretest-posttest desain. Dalam desain ini, sebelum perlakuan diberikan terlebih dahulu sampel diberi pretest (tes awal) dan pada akhir pembelajaran sampel diberi posttest (tes akhir). Desain ini digunakan sesuai dengan tujuan yang hendak dicapai yaitu ingin 
mengetahui peningkatan hasil belajar siswa setelah diterapkan metode pembelajaran Teams Games Tournament berbantuan permainan dadu.

Teknik yang dipakai untuk mengumpulkan data dalam penelitian ini adalah teknik observasi dan teknik tes. Sedangkan instrumen pengumpulan data dalam penelitian ini adalah lembar observasi, dan butir soal tes dengan bentuk pilihan ganda.Analisis data yang digunakan dalam penelitian ini adalah analisis deskriptif kuantitatif. Data hasil belajar IPA yang terkumpul dari hasil belajar IPA dilakukan analisis deskriptif dan analisis parametrik. Untuk analisis deskriptif data menggunakan deskriptif statistik dan analisis parametrik yaitu pendugaan dan uji hipotesis dari parameter varian didasarkan pada anggapan bahwa skor-skor ditarik dalam suatu varian dengan distribusi tertentu. Untuk analisis parametrik data yang digunakan adalah Uji T-test. Analisis data penelitian ini menggunakan SPSS 20 for windows.

\section{HASIL PENELITIAN DAN PEMBAHASAN}

Dalam penelitian ini pengumpulan data hasil belajar IPA siswa kelas 3A SDN Lemahireng 02 Bawen menggunakan teknik pretest-posttest yaitu sebelum siswa diberi perlakuan (treatment) dengan menggunakan metode Teams Game Tournament berbantuan permainan dadu siswa diberikan pretest terlebih dahulu untuk mengukur kemampuan siswa dalam memahami materi yang dalam pembelajarannya diampu oleh guru menggunakan metode pembelajaran diskusi.

\section{Hasil Analisis Deskriptif Pretest}

Jumlah soal posttest sebanyak 30 butir soal pilihan ganda diambil dari soal yang valid setelah dianalisis validitas, reliabilitas, dan tingkat kesukaran instrument tes. Berdasarkan kriteria ketuntasan minimal (KKM 263 ) data hasil perolehan nilai pretest (sebelum diberikan perlakuan) dapat dilihat pada tabel 1 .

Tabel 1

Ketuntasan Hasil Belajar Pretest

\begin{tabular}{|l|c|c|c|}
\hline \multirow{2}{*}{ Kategori } & \multirow{2}{*}{ Range } & \multicolumn{2}{c|}{ Pretest } \\
\cline { 3 - 4 } & & Frekuensi & Persentase (\%) \\
\hline Tuntas & $63-100$ & 8 & $29,6 \%$ \\
\hline Tidak tuntas & $0-62$ & 19 & $70,4 \%$ \\
\hline Jumlah & 27 & $100 \%$ \\
\hline
\end{tabular}

Dari tabel 1 menunjukkan bahwa ketuntasan hasil belajar pretest dapat dijelaskan bahwa siswa yang memperoleh nilai kurang dari kriteria ketuntasan minimal (KKM 263 ) sebanyak 19 siswa atau 70,4\% dari 27 siswa. sedangkan yang sudah mencapai kriteria ketuntasan minimal (KKM 263) sebanyak 8 siswa atau 29,6\% dari 27 siswa.

Distribusi selanjutnya dilakukan analisis deskriptif. Di bawah ini merangkum data empirik sebelum diberikan perlakukan pembelajaran (pretest) menggunakan metode Teams Game Tournament berbantuan permainan dadu pada pelajaran IPA siswa kelas 3A SDN Lemahireng 02 Bawen yang telah diklasifikasikan pada tabel 2 Descriptive 
Statistics di bawah ini dengan ukuran tendensi sentral (Mean), pengukuran penyimpangan (Range, Standar Deviation, dan Variance).

Tabel 2

Descriptive Statistics Pretest

\begin{tabular}{|l|c|c|c|c|c|c|c|}
\hline \multicolumn{7}{|c|}{ Descriptive Statistics } \\
\hline & N & Range & Minimum & Maximum & Mean & $\begin{array}{c}\text { Std. } \\
\text { Deviation }\end{array}$ & Variance \\
\hline PretTest & 27 & 43 & 40 & 83 & 57.01 & 12.648 & 159.970 \\
\hline $\begin{array}{l}\text { Valid N } \\
\text { (listwise) }\end{array}$ & 27 & & & & & & \\
\hline
\end{tabular}

Tabel 2 menunjukkan jumlah (N) sebanyak 27 mempunyai rentangan (range) sebesar 43. Selanjutnya, skor maksimal 83 sedangkan skor minimal sebesar 40 dengan rata-rata hitung (mean) 57,01. Kemudian, standar deviasi (Std. Deviation) sebesar 12,648. Terakhir memiliki nilai varians (variance) sebesar 159,970.

\section{Hasil Analisis Deskriptif Posttest}

Posttest dilakukan untuk mengukur pengaruh penerapan metode Teams Game Tournament berbantuan permainan dadu dalam pembelajaran IPA siswa kelas 3A SDN Lemahireng 02 Bawen. Jumlah soal posttest sebanyak 30 butir soal pilihan ganda diambil dari soal yang valid setelah dianalisis validitas, reliabilitas, dan tingkat kesukaran instrument tes.

Berikut ini akan disajikan tabel distribusi frekuensi skor hasil belajar posttest. Berdasarkan kriteria ketuntasan minimal (KKM 263 ) data hasil perolehan nilai posttest (setelah diberikan perlakuan) dapat dilihat pada tabel 3 berikut ini.

Tabel 3

Ketuntasan Hasil Belajar Posttest

\begin{tabular}{|l|c|c|c|}
\hline \multirow{2}{*}{ Kategori } & \multirow{2}{*}{ Range } & \multicolumn{2}{c|}{ Pretest } \\
\cline { 3 - 4 } & & Frekuensi & Persentase (\%) \\
\hline Tuntas & $63-100$ & 22 & $81,5 \%$ \\
\hline Tidak tuntas & $0-62$ & 5 & $18,5 \%$ \\
\hline Jumlah & & 27 & $100 \%$ \\
\hline
\end{tabular}

Dari tabel 3 menunjukkan bahwa ketuntasan hasil belajar posttest dapat dijelaskan bahwa siswa yang memperoleh nilai kurang dari kriteria ketuntasan minimal (KKM $\geq 63$ ) sebanyak 5 siswa atau 18,5\% dari 27 siswa. sedangkan yang sudah mencapai kriteria ketuntasan minimal (KKM $\geq 63$ ) sebanyak 22 siswa atau 81,5\% dari 27 siswa.

Distribusi selanjutnya dilakukan analisis deskriptif. Di bawah ini merangkum data empirik setelah diberikan perlakukan pembelajaran (posttest) menggunakan metode Teams Games Tournament berbantuan permainan dadu pada pelajaran IPA siswa kelas 3A SDN Lemahireng 02 Bawen, telah diklasifikasikan pada tabel 4 Descriptive Statistics di bawah ini dengan ukuran tendensi sentral (Mean), pengukuran penyimpangan (Range, Standar Deviation, dan Variance). 
Tabel 4

Descriptive Statistics Posttest

\begin{tabular}{|l|c|c|c|c|c|c|c|}
\hline \multicolumn{7}{|c|}{ Descriptive Statistics } \\
\hline & N & Range & Minimum & Maximum & Mean & $\begin{array}{c}\text { Std. } \\
\text { Deviation }\end{array}$ & Variance \\
\hline PostTest & 27 & 37 & 57 & 93 & 72.10 & 10.218 & 104.400 \\
\hline $\begin{array}{l}\text { Valid N } \\
\text { (listwise) }\end{array}$ & 27 & & & & & & \\
\hline
\end{tabular}

Tabel 4 menunjukkan jumlah $(\mathrm{N})$ sebanyak 27 mempunyai rentangan (range) sebesar 37. Selanjutnya, skor maksimal 93 sedangkan skor minimal sebesar 57 dengan rata-rata hitung (mean) 72,10. Kemudian, standar deviasi (Std. Deviation) sebesar 10,218. Terakhir memiliki nilai varians (variance) sebesar 104,400.

\section{Hasil Uji Hipotesis}

Untuk melakukan dan mendapatkan hasil dari Uji T-test berpasangan maka dapat menggunakan bantuan SPSS 20.0 dengan Statistik Paired Sample T-test. Uji ini digunakan untuk mengetahui ada atau tidaknya perbedaan rata-rata antara dua kelompok sampel yang berpasangan (berhubungan). Maka Uji T-tes (Paired Sample T-test) dalam penelitian ini digunakan untuk mengetahui perbedaan hasil belajar siswa sebelum dan sesudah pembelajaran menggunakan metode Teams Games Tournament berbantuan permainan dadu pada pelajaran IPA. Dalam penelitian ini uji perbedaan dua rata-rata dilakukan pada nilai pretest dan nilai posttest dari subjek penelitian.

Uji T-test (Paired Samples T-test) untuk mengetahui signifikansi perbedaan ratarata nilai pretest dan posttest. Hasil uji T-test (Paired Samples T-test) dari nilai pretest dan post-tets hasil belajar IPA dapat dilihat pada tabel 5 .

\section{Tabel 5}

Uji T-test Skor pretest dan posttest Hasil Belajar IPA

\begin{tabular}{|c|c|c|c|c|c|c|c|c|c|}
\hline \multicolumn{10}{|c|}{ Paired Samples Test } \\
\hline & & \multicolumn{5}{|c|}{ Paired Differences } & \multirow{3}{*}{$\mathrm{t}$} & \multirow{3}{*}{ df } & \multirow{3}{*}{$\begin{array}{l}\text { Sig. (2- } \\
\text { tailed) }\end{array}$} \\
\hline & & \multirow[t]{2}{*}{ Mean } & \multirow[t]{2}{*}{$\begin{array}{c}\text { Std. } \\
\text { Deviation }\end{array}$} & \multirow[t]{2}{*}{$\begin{array}{l}\text { Std. } \\
\text { Error } \\
\text { Mean }\end{array}$} & \multicolumn{2}{|c|}{$\begin{array}{l}\text { 95\% Confidence } \\
\text { Interval of the } \\
\text { Difference }\end{array}$} & & & \\
\hline & & & & & Lower & Upper & & & \\
\hline Pair 1 & $\begin{array}{l}\text { Pre-Post } \\
\text { Test }\end{array}$ & 15.086 & 6.966 & 1.341 & 12.331 & 17.842 & 11.253 & 26 & .000 \\
\hline
\end{tabular}

Tabel 5 menunjukkan hasil t-hitung yang telah dilakukan diperoleh dengan menggunakan Paired Samples Test. Pada kolom Sig (2-tailed) diperoleh nilai 0,000. Jika pada rumusan hipotesis yaitu $\mathrm{H}_{0}$ : Tidak ada perbedaan yang signifikan antara penggunaan metode Teams Games Tournament berbantuan permainan dadu dengan metode pembelajaran diskusi terhadap hasil belajar IPA siswa kelas 3 SDN Lemahireng 02, dengan nilai sig $>0,05 . \mathrm{H}_{\alpha}$ : Terdapat perbedaan yang signifikan antara penggunaan metode Teams Games Tournament berbantuan permainan dadu dengan metode pembelajaran diskusi terhadap hasil belajar IPA siswa kelas 3 SDN Lemahireng 02 Bawen dengan nilai sig $<0,05$. Maka dari hasil output disimpulkan bahwa $\mathrm{H}_{\alpha}$ diterima 
karena sig $<0,05$ yaitu $0,000<0,05$. Dengan demikian dapat diambil keputusan bahwa hasil belajar IPA siswa (pretest) sebelum diberi perlakuan berbeda dengan hasil belajar siswa (posttest) setelah diberi perlakuan menggunakan metode Teams Games Tournament berbantuan permainan dadu. Nilai rata-rata pembelajaran sesudah menggunakan metode Teams Games Tournament berbantuan permainan dadu lebih tinggi dari nilai rata-rata pembelajaran sebelum menggunakan metode Teams Games Tournament berbantuan permainan dadu. Dengan demikian disimpulkan bahwa terdapat perbedaan hasil belajar yang signifikan antara penggunaan metode Teams Games Tournament berbantuan permainan dadu dengan metode pembelajaran diskusi pada mata pelajaran IPA siswa kelas 3A SDN Lemahireng 02 Bawen.

\section{Pembahasan}

Berdasarkan uji validitas, uji reliabilitas, dan tingkat kesukaran yang telah diberikan sebanyak 40 soal, penggunaan soal sebagai pretest dan posttest sebanyak 30 butir soal. Hasil pretest dan posttest dianalisis menggunakan uji normalitas yang menunjukkan instrumen pretest dan posttest mempunyai data pada One-Sample Kolmogorov-Smirnov Test dengan tingkat signifikansi (Asymp. Sig. (2-tailed)) 0,416 untuk pretest dan Asymp. Sig. (2-tailed) 0,297 untuk posttest. Jika dirumuskan 0,416 > 0,05 (pretest) dan 0,297>0,05 (posttest). Dengan demikian dapat disimpulkan bahwa kedua data pretest dan posttest dinyatakan berdistribusi normal dengan tingkat signifikasi $>0,05$. Selanjutnya hasil pretest dan posttest dianalisis menggunakan uji hipotesis, dalam melakukan uji hipotesis menggunakan Uji T-test berpasangan dengan bantuan SPSS 20.0 dengan Statistik Paired Sample T-test. Hasil uji T-test (Paired Samples T-test) dari nilai pretest dan post-tets hasil belajar IPA menunjukkan nilai 0,000 pada kolom Sig (2-tailed). Jika pada rumusan hipotesis yaitu $\mathrm{H}_{0}$ : Tidak ada perbedaan yang signifikan antara penggunaan metode Teams Games Tournament berbantuan permainan dadu dengan metode pembelajaran diskusi terhadap hasil belajar IPA siswa kelas 3 SDN Lemahireng 02 Bawen, dengan nilai sig > 0,05. $\mathrm{H}_{\alpha}$ : Terdapat perbedaan yang signifikan antara penggunaan Teams Games Tournament berbantuan permainan dadu dengan metode pembelajaran diskusi terhadap hasil belajar IPA siswa kelas 3 SDN Lemahireng 02 Bawen dengan nilai sig $<0,05$. Maka dari hasil output disimpulkan bahwa $\mathrm{H}_{\alpha}$ diterima karena sig $<0,05$ yaitu $0,000<0,05$. Dengan demikian dapat diambil keputusan bahwa hasil belajar IPA siswa (pretest) sebelum diberi perlakuan berbeda dengan hasil belajar siswa (posttest) setelah diberi perlakuan menggunakan metode Teams Games Tournament berbantuan permainan dadu. Hal ini dibuktikan dengan hasil rata-rata nilai posttest (setelah diberikan perlakuan) yaitu 72,1 dengan nilai terendah 57 dan nilai tertinggi 93 yang lebih tinggi dibandingkan hasil rata-rata nilai pretest (sebelum diberikan perlakuan) yaitu 57 dengan nilai terendah 40 dan nilai tertinggi 83. Dilihat dari jumlah siswa yang tuntas nilai pre-test sesuai dengan kriteria ketuntasan minimal (KKM 263$)$ sebanyak 8 siswa atau 29,6\% dari 27 siswa. Sedangkan nilai posttest sebanyak 22 siswa atau 81,4\% dari 27 siswa.

Hasil penelitian ini menguatkan bahwa Teams Games Tournament berpengaruh positif terhadap peningkatan hasil belajar IPA siswa, apalagi TGT diimplementasikan berbantuan permainan dadu dengan metode pembelajaran diskusi; Temuan penelitian ini 
sejalan dengan dengan temuan Sari, I. A. K. (2012) Rakhmadhani, N., Yamtinah, S., \& Utomo, S. B. (2013) dan Agustini, N. M., Dibia, I. K., \& Suartama, I. K. (2014). Mengapa demikian? Hasil penelitian yang mampu menjelaskan adalah Sari dan Ika Ayu Kartika (2012), dengan TGT menunjukan adanya peningkatan antusias dan tertariknya siswa dalam belajar yang pada akhirnya berdampak pada meningkatnya hasil belajar siswa. Diduga kuat dengan penggunaan permainan dadu dalam TGT, antusias siswa meningkat karena lebih tertarik untuk belajar; sehingga hasil belajar siswa meningkat (Mufida, N. (2010); Susilowati, D. (2014); Mufida, N. (2010); Partana, C. F. (2016); Efendi, O. A., Slamet, H. W., \& Pd, M. (2016).

\section{SIMPULAN}

Setelah melakukan penelitian didapatkan kesimpulan berdasarkan hipotesis yang telah dirumuskan dan dinyatakan "Terdapat perbedaan yang signifikan antara penggunaan metode Teams Games Tournament berbantuan permainan dadu dengan metode pembelajaran diskusi terhadap hasil belajar IPA siswa kelas 3 SDN Lemahireng 02 Bawen Kabupaten Semarang Semester II Tahun Ajaran 2015/2016”. Hal ini dikarenakan siswa tertarik dan merasa senang dalam mengikuti pembelajaran dan dibuktikan dengan hasil rata-rata nilai posttest setelah diberikan perlakuan menggunakan metode Teams Games Tournament berbantuan permainan dadu yaitu sebesar 72,1 lebih tinggi dibandingkan dengan hasil nilai rata-rata pretest sebelum diberikan perlakuan yaitu sebesar 57.

\section{SARAN}

Penulis memberikan beberapa saran diantaranya ialah saran teoritis yaitu dengan menggunakan metode pembelajaran Teams Games Tournament berbantuan permainan dadu dapat digunakan sebagai salah satu cara untuk menimbulkan ketertarikan dalam belajar yang berpengaruh pada hasil belajar siswa dalam pelajaran IPA, selain itu saran praktisnya ialah:

a. Bagi siswa

Dari hasil penelitian terbukti bahwa pembelajaran menggunakan metode Teams Games Tournament berbantuan permainan dadu telah memberi suasana belajar yang menyenangkan sehingga pembelajaran yang diikuti lebih terlihat bermakna karena memberikan gambaran tentang konsep pelajaran IPA yang menyenangkan dan menjadikan siswa aktif terlibat untuk berinteraksi dengan rekan sebaya serta termotivasi sehingga hasil belajar siswa meningkat. Dalam hal ini peneliti memberikan saran pada siswa untuk lebih semangat dan tingkatkan aktifitas dalam mengikuti pembelajaran sesuai dengan metode yang digunakan agar pembelajaran berlangsung secara efektif dan efisien sesuai yang diharapkan.

b. Bagi guru

Guru diharapkan mampu meningkatkan kualitas pembelajaran dan mengembangkan metode pembelajaran agar lebih kreatif dalam merencanakan, menerapkan, dan memilih metode pembelajaran agar tidak membuat siswa merasa jenuh dalam proses pembelajaran.Sebelum proses pembelajaran berlangsung hendaknya guru lebih tanggap terhadap kondisi atau karakter siswa dan materi yang akan dipelajari. 
Sehingga pemilihan metode yang digunakan sesuai dengan karakter siswa dan materi yang akan dipelajari.

c. Bagi Kepala Sekolah

Dalam penelitian ini kepala sekolah diharapkan memberikan pengarahan dengan membina guru terkait dengan penggunaan metode pembelajaran dalam usaha perbaikan proses pembelajaran para guru dan hasil belajar siswa.

\section{DAFTAR PUSTAKA}

Agustini, N. M., Dibia, I. K., \& Suartama, I. K. 2014. Pengaruh Model Pembelajaran Team Game Tournament (TGT) Berbantuan Media Flip Chart Terhadap Hasil Belajar IPA Siswa Kelas V SD. Mimbar PGSD, 2(1).

Bannett Neville, Liz Wood \& Sue Rogers. 2005. Teaching Through Play Teacher's thinking and classroom practice. Jakarta: PT Gramedia Widiasarana Indonesia.

Departemen Agama R.I., 2002. Metodologi Pendidikan Agama Islam.Jakarta: Direktorat Jendral Kelembagaan Agama Islam.

Depdiknas. 2006. Undang-undang Republik Indonesia Nomor 20 Tahun 2003 Tentang Sistem Pendidikan Nasional. Jakarta.

Efendi, O. A., Slamet, H. W., \& Pd, M. 2016. Pengaruh Model Pembelajaran Numbered Head Together (NHT) dan Teams Games Tournament (TGT) Terhadap Hasil Belajar Matematika Ditinjau Dari Gaya Belajar Siswa Kelas VII Semester Genap MTs Negeri Surakarta 1 Tahun 2015/2016 (Doctoral dissertation, Universitas Muhammadiyah Surakarta).

Fathurrohman Muhammad. 2015. Model-Model Pembelajaran Inovatif. Yogyakarta: ArRuzzmedia.

Hamdani, 2011.Strategi Belajar Mengajar. Bandung: Pustaka Setia

Mufida, N. 2010. Eksperimentasi Model Pembelajaran Kooperatif Tipe Teams Games Tournament (TGT) pada Pokok Bahasan Bangun Ruang Sisi Lengkung Ditinjau dari Gaya Belajar Siswa Kelas IX MTs Negeri Se-Kabupaten Klaten Tahun Pelajaran 2009/2010 (Doctoral dissertation. Surakarta: UNS. Tidak diterbitkan).

Mulyasa. 2008. Implementasi Kurikulum Tingkat Satuan Pendidikan Kemandirian Guru dan Kepala Sekolah.Jakarta: PT Bumi Aksara.

Partana, C. F. 2016. Kajian Efektivitas Penerapan Metode Pembelajaran Kooperatif Tipejigsaw dan STAD Pada Mata Pelajaran IPA Aspek Kimia di SMP2 Mlati Sleman. Jurnal Cakrawala Pendidikan, 2(2).

Peraturan Mentri Pendidikan Nasional Nomor 41 Tahun 2003 tentang Sistem Pendidikan Nasional.2003. Jakarta: Kementerian Pendidikan Nasional.

Rakhmadhani, N., Yamtinah, S., \& Utomo, S. B. 2013. Pengaruh Penggunaan Metode Teams Games Tournaments Berbantuan Media Teka-Teki Silang Dan Ular Tangga Dengan Motivasi Belajar Terhadap Prestasi Siswa Pada Materi Koloid Kelas XI SMA Negeri 1 Simo Tahun Pelajaran 2011/2012. Jurnal Pendidikan Kimia, 2(4), 190-197. 
Pengaruh Penerapan Metode Teams Games Tournament Berbantuan permainan Dadu Terhadap Hasil Belajar IPA (Eka Rizki Widayanti, Slameto)

Robert E. Slavin. 2006.Educational Psychology: Theory and Practice eighth edition, terj: Drs. Marianto Samosir, S. H, Psikologi pendidikan : Teori dan praktik edisi kedelapan jilid 2. Jakarta: Indeks.

Samatowa Usman. 2011. Pembelajaran IPA di SEKOLAH DASAR. Jakarta: PT. Indeks.

Sanjaya Wina. 2008. Kurikulum dan Pembelajaran Teori dan Praktik Pengembangan Kurikulum Tingkat Satuan Pendidikan (KTSP). Jakarta: Kencana.

Sari, I. A. K. 2012. Penerapan model TGT melalui metode permainan monopoli untuk meningkatkan motifasi dan prestasi belajar fisika siswa kelas X-2 SMA Negeri 1 Nganjuk tahun pelajaran 2011/2012.

Susilowati, D. 2014. Studi Komparasi Hasil Belajar Akuntansi Dengan Penerapan Metode Pembelajaran Teams Games Tournament (TGT) Dengan Metode Ceramah Bervariasi Pada Kompetensi Dasar Jurnal Khusus Siswa Kelas Xii Ips Sma Muhammadiyah 01 Pati. Economic Education Analysis Journal, 2 (3), 24-35.

Trianto. 2012. Model Pembelajaran Terpadu Konsep, Strategi, dan Implementasinya dalam Kurikulum Tingkat Satuan Pendidikan (KTSP). Jakarta: PT Bumi Aksara. 